\title{
Correction to: Construction of the Monetary Conditions Index with TVP-VAR Model: Empirical Evidence for Turkish Economy
}

\author{
Coşkun Akdeniz
}

\section{Correction to:}

Chapter 9 in: B. Adıgüzel Mercangöz (ed.), Handbook of Research on Emerging Theories, Models, and Applications of Financial Econometrics, https://doi.org/10.1007/978-3-030-54108-8_9

This book was inadvertently published with a spelling error in the chapter title and incorrect values on page 222, which have now been corrected. The value for the highest positive response of the output gap to short-term interest rate change was adjusted from $30 \%$ to $3.0 \%$. The value for the highest response to the real exchange rate change was adjusted from $25 \%$ to $2.5 \%$. This is now available as a new last chapter and is included in the book. 